\title{
1 \\ The China boom and its discontents
}

Ross Garnaut

Chinese economic growth is less problematic now than at any time since the beginnings of reform more than a quarter of a century ago.

Economic growth last year and this is proceeding at an annual rate around nine and a half per cent, which is the average rate of the reform period. The deflation of the early twenty-first century has ended, without being replaced by worrying degrees of inflationary pressure. Last year's concerns about excessive investment in stateowned heavy industry have been eased by restrictions on bank credit and a modest increase in interest rates. Current external payments have moved into surplus to an extent that is generating international anxieties, and which requires correction, but on a scale that can be corrected without dislocation. Direct foreign investment is high and increasing, contributing much to productivity growth. The private sector continues to grow rapidly, as a share of total activity as well as absolutely, with artificial restrictions on its expansion being removed progressively. The stateowned enterprises are shrinking steadily as a share of the economy, their number is falling absolutely with restructuring including sale into the private sector, and the financial performance of those which remain is improving with reform.

China is reaping large benefits from reform prompted by WTO membership, facilitating deeper integration into the international economy. Over the past year, China has overtaken Japan as the world's third largest participant in international trade. It continues to be the world's major destination for direct foreign investment. China's growth has systematically raised global prices of its main import products and reduced prices for its main exports. The world has come to see China as by far the most rapidly growing competitive threat and market opportunity. 
These are amongst the characteristics of the Chinese economy in 2005. The international official and business communities are talking about a China boom, but they are actually feeling the huge but foreseeable impact of a very large economy on a path of rapid growth that is broadly familiar from earlier East Asian experience. The reality is business as normal.

The discontents of the apparent boom include Chinese who are participating less than their fellow citizens in the rising tide of prosperity. They include those who are exposed more than others to the risks and pressures for structural change in patterns of production that come with prosperity and success. They include foreigners subjected to the need for structural change as China expands its role in international business.

There have always been voices predicting inevitable failure of the vast contemporary Chinese experiment in reform and growth — a Leninist State presiding over the establishment of a modern market economy; the government of a backward, inward-looking society and economy aspiring to deeper integration into the international economy than most of the advanced industrial countries; and a population larger than the sum of all of the countries that have become rich since modern economic growth began in Britain a quarter of a millennium ago, aspiring to the attainment of the living standards of the world's most prosperous peoples within a couple of generations.

Those who said that Chinese reform would not succeed are already wrong. The debates about whether modern, internationally oriented growth could take root in China, at all or under Communist Party rule, have been settled by reality. The optimists in these debates were themselves wrong, because they were too timid in calling the scale and speed of China's economic transformation. The pessimists about China over the past quarter century-the legions of commentators who have said that the establishment of a modern economy in China was too large, too strange to any earlier precedents of history ever to succeed—are scrambling out of the dust bin of history.

But the wiser optimists about Chinese structural transformation and economic growth have always recognised that there would be exclusions and victims of prosperity, generating threats to stable economic growth if ways were not found to assuage their resentments. They always recognised that the modernisation of China, like that of the communities of Europe, North America, Japan and the smaller newly industrialised economies of East Asia before it, would have bumps in the road, false turns that would have to be reversed and corrected, and detours from the main path of economic, social and political transformation. They always recognised that the transformation of the authoritarian political system that would 
be nurtured by successful economic transformation would be fraught with risks to stability and from time to time to economic growth.

This book is mainly about some of the risks to and problems associated with the inexorable but uneven emergence of China as a high-income economy and modern society.

Garnaut and Huang in Chapter 2 seek to answer a question that has been on the minds of many economists, especially in the business sector. Can China's extraordinarily high investment levels continue to fuel growth? Or would the continuation of the high and rising investment rates of recent years-higher than any the world has ever seen, excepting only Singapore for a brief period in the 1980s—create problems that ended or slowed growth?

Garnaut and Huang reach the surprising (in the light of the current domestic and international economic discussion) conclusion that the correction of current imbalances may require higher rather than lower investment rates, and that this will be associated with higher rather than lower growth rates.

This is a conclusion that emerges from the application of standard economic analysis to contemporary Chinese data. China has underutilised resources of labour and human capital (Chapters 6 and 7), and some underutilised industrial capacity. Indeed, unemployment and underemployment represent large loss of economic opportunity and a large social and political problem. While there are some bottlenecks inhibiting economic expansion-for example in electric power and some forms of transportation-there is no general inflationary problem. A residential property boom is raising the costs of housing in some cities, but even in these places it is smaller than that in the large cities of the United States, Australia and Britain in recent years, and it is of modest importance on a national scale. The domestic economic imbalance is one of inadequate rather than excessive activity.

At the same time, China in 2005 is experiencing a large external payments surplus on both current and capital accounts-the latter partly speculative in response to the former and to the widespread expectation of currency appreciation. The huge and rapidly growing foreign exchange reserves-mostly invested in United States' financial assets at low rates of return-represent an opportunity forgone to expand current and future living standards in a country which is still far from meeting the aspirations for material progress of its people.

One can see the current account surplus as the excess of prodigiously high savings over very high investment. Chinese private and government consumption expenditure have both been rising rapidly, but not at the rate of incomes. Savings have been rising - partly as a precaution against old age and ill health; partly in 
response to rising private investment opportunities; but above all as consumer desires and preferences have lagged behind the increase in incomes. Various government policy measures to encourage consumption-more and longer holidays, new taxes on bank interest receipts-have had only marginal effects on the flood of savings.

The high savings in contemporary China are to a considerable extent the product of rapid growth itself. They would be affected to some degree by reforms to the financial sector that increased confidence in the security of and earnings on longterm savings, and allowed earlier access to higher quality private housing and consumer durables. But they are going to remain high for the foreseeable future, and may go higher with continued and possibly accelerating economic growth.

In Japan, a tendency towards huge excess of private incomes over consumption is offset in part by large fiscal deficits-to the extent that Japanese public debt, in absolute terms and as a share of GDP, is by far the highest of the advanced economies. China, with good reason, is deeply resistant to pursuing such a course. The good reasons begin with the potential for financial fragility in a developing economy with a weak financial sector. The state-owned banks owe their stability to state guarantees that would be fiscally demanding should they be called. It is prudent for the time being to nurture the fiscal capacity to stand by the banks. It is sensible as well to avoid the disincentives to economic activity that would be inherent in the need to raise large amounts of taxation revenue to service public debt.

There is scope for fiscal expansion at the margin, but the Chinese authorities are wise not to make expanding fiscal deficits a central part of economic development strategy. The expansion at the margin could nevertheless have a useful impact in raising demand, prospects for long-term growth and also incomes and lifetime prospects of low-income people. To generate all of these effects, increased government expenditure would need to be directed carefully towards the expansion of such public services as education in rural China, and for the children of migrants from rural China to the great cities.

The external payments surplus and the high rates of investment, much of it in export industries, and China's sustained high rates of economic growth, have led to calls from abroad to reduce investment and raise the foreign exchange value of the renminbi. The Chinese authorities responded to the international pressures, and to some domestic analysis that followed the path of the emerging international conventional wisdom, in July, by appreciating the renminbi by 2.1 per cent and shifting the currency peg from the US dollar to a basket of currencies of important trading partners. This followed a lift in regulated interest rates in 2004, designed to reduce investment and economic growth. A common macroeconomic prescription 
in China and abroad favours more monetary tightening and currency appreciation. China's internal economic imbalances argue for more not less domestic expenditure. With limited scope for increases in public expenditure and private consumption in the short term, a substantial part of any expansion would need to be contributed from investment.

The impact of increased investment on Chinese growth prospects would depend greatly on the manner in which it was stimulated. An expansion of direct Government investment, and lending by state-owned banks to other state-owned businesses, along the lines of the Keynesian expansion that maintained growth at reasonable rates through the East Asian financial crisis, would perpetuate the current disappointing contribution of investment to long-term growth. If public expenditure expansion is to play a role, it would be much better for it to be focused on investment in human capital formation amongst lower-income Chinese. Financial sector reform, which would have the effect of facilitating increases in bank lending to the productive and rapidly growing private sector, and would generate better outcomes for productivity and economic growth than expanding state-owned enterprises' access to capital.

An increase in absorption would in itself reduce the external payments surplus and pressure for additional appreciation of the exchange rate. An acceleration of liberalisation of trade in goods and services-abolition of import quotas, reductions in tariffs, and removal of remaining constraints on current payments for tourism and other services - would have additional impacts in the same direction. These would seem to be the most productive first steps in moderating the external payments surpluses.

It is possible that excessive payments surpluses would remain after taking domestic expenditure expansion and trade and payments liberalisation to their prudent limits. Exchange rate appreciation would be useful as a third element in a strategy to establish an appropriate balance in external payments. The systemic changes announced in July after a long period of preparation strengthen the base for such adjustment.

The monetary authorities have been undertaking preparatory work towards a market-oriented foreign exchange system for a year and more. Major steps have included the authorisation of trade in a wide range of currencies and the encouragement of institutional development in the financial sector to facilitate active trade in foreign exchange. The much-heralded steps in July 2005, were not in themselves of decisive importance for economic adjustment-a small appreciation, the fixing of the renminbi's value daily against a basket of currencies, and the 'floating' of the currency within a daily band of plus and minus 0.3 per cent against a mid-point for the United States dollar. But they undoubtedly reduce the 
risks of, and bring closer, an eventual move towards a freely floating rate and capacity for economically meaningful exchange rate adjustment.

The change in the renminbi parity after a decade and more fixed firmly against the United States dollar may have the unwanted effect of encouraging speculation in anticipation of further and larger appreciation. The immediate economic effect of this would be to accelerate monetary expansion, thus contributing to the expenditure expansion that would be part of an optimal macro-economic strategy in current circumstances. It may bring forward the time when official China recognises the need for larger change in the foreign exchange regime and rate. Adjustment under speculative pressure along these lines is likely to carry more risks of over-shooting and more generally of instability than purposeful change in the settings of policy instruments affecting expenditure, liberalisation of trade and payments, and the exchange rate.

Through one mechanism or another, China is likely to see higher rates of investment and economic growth in the period ahead than over the past half dozen years. This will disappoint foreign commentators who have seen a large exchange rate adjustment as a means of reducing Chinese growth.

Ding and Zheng in Chapter 3 examine the exchange rate issue in more detail, and are generally cautious about the extent of exchange rate appreciation that could be sustained without major dampening effects on Chinese economic growth.

Chapters 4 and 5 look closely at the deep wellsprings of Chinese growth. Fang and Wang examine the contribution of favourable demographic factors in strong economic growth in East Asia over the past half-century. A high ratio of work-age to total population assists economic growth in a number of ways, and China has been a beneficiary through recent years and will remain so for a considerable period ahead. But a severe and unfavourable demographic transition will follow, as the offspring of the one-child policy in the reform era come to dominate the labour force, and as the children of the earlier era, living longer with improved nutrition and health services, survive through many years of retirement. China needs to do well economically in the years of favourable demographic balances, to support high living standards beyond.

Kong addresses one of the most important and elusive questions of economic development: what is the optimal political system for economic development, and how do China's institutions compare with what would work best. Her analysis demonstrates that neither an excessively weak State, nor one that is excessively dominant over the lives and decisions of its citizens, will produce strong, sustained economic growth. The Chinese State was too dominant and intrusive in the Maoist era. Despite the continuation of one-party rule through the reform period, there 
has in fact been considerable political liberalisation affecting the lives and decisions of ordinary people. This has been crucial to the success of market-oriented reform. It is a lesson of the global development experience that the optimal balance between the strength of the State and the autonomy of the individual changes with the progress of economic development. If Chinese growth is to be sustained over long periods, the political system will need to continue to evolve.

In Chapters 6 and 7, Wang, Song and Sheng discuss the important issues surrounding rural-urban migration and urbanisation in the process of economic growth. The availability of large amounts of labour that can move from agricultural to urban employment with little sacrifice of agricultural output is a source of resources for rapid, non-inflationary growth. Migration is an important mechanism for raising incomes of people resident in rural areas. But current policy settings in China deliver inadequate services and incomes to many people in and from rural areas. There is also a large backlog of investment in urban services that has to be corrected if migrants and their children are to participate fully in the opportunities in China's dynamic market economy.

In Chapters 9 and 12, Meng and Murton discuss aspects of the rapidly changing system of social security and welfare in urban China. Meng demonstrates, against the conventional wisdom in China and abroad, that the restructuring of stateowned enterprises has favourable effects over time on labour market outcomes and employees' welfare. Murton describes and assesses the effects of the farreaching changes in social security arrangements that have been introduced alongside the disintegration of the old safety nets built around secure employment in state-owned enterprises.

Wen (Chapter 8), Liu, Hamdoun and Dickinson (Chapter 10) and Rule (Chapter 11) discuss corporate aspects of China's emerging market economy. The general picture is one of extraordinarily rapid evolution of Chinese enterprises, their governance, and the markets through which their ownership rights are traded. The scale of the task means that, despite extraordinary rates of change, much of the challenge of reform, structural change and institutional development still lies ahead. The pace of change means that there are risks of error and misjudgment that could have disruptive consequences. But the achievements so far are a source of confidence that Chinese development in these areas will over time meet the demanding requirements of continued rapid growth.

Finally, Athukorala in Chapter 13 and Li and Song in Chapter 14 discuss changes in the structure of Chinese foreign trade that are accompanying rapid, internationallyoriented economic growth. Athukorala draws attention to and analyses the increasingly important role of trade in components in China's export 
competitiveness. This is one reason why China's rapid economic growth is assisting and not detracting from the export performance of many of its East Asian neighbours. He cautions that the increasing importance of discriminatory bilateral trading arrangements may undermine this beneficent dimension of globalisation in the East Asian region, with harmful effects on Chinese export competitiveness, and more damaging effects on the economies that have received large benefits from the export of components to China's burgeoning export industries. Li and Song demonstrate more generally that Chinese trade expansion has contributed opportunities through export expansion and specialisation to other Asia Pacific economies, at the same time as it has placed them under great pressure for structural change.

The overall story of Chinese economic development in 2005 is one of immense stress, and of many problems associated with fundamental change inside China and amongst its trading partners. But this year more than at any earlier time in the reform period, it is a time of confidence that the challenges of change are being met, and that China is on course in its fast but long journey towards the productivity, incomes and living standards of the world's advanced economies. 